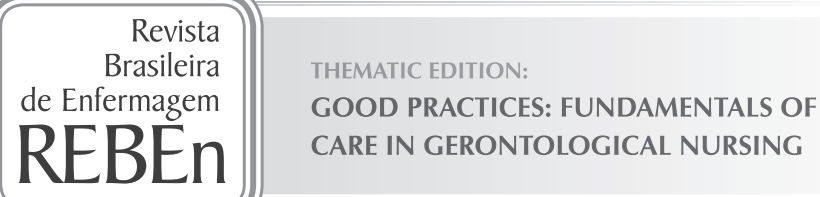

\title{
Health education with older adults: action research with primary care professionals
}

Educação em saúde com idosos: pesquisa-ação com profissionais da atenção primária

Educación en salud para los ancianos: la investigación-acción con los profesionales de atención primaria

\section{Francielle Toniolo Nicodemos Furtado de Mendonça', Álvaro da Silva Santos', Ana Luisa Zanardo Buso', Bruna Stephanie Sousa Malaquias'}

' Universidade Federal do Triângulo Mineiro, Postgraduate Program in Health Care. Uberaba, Minas Gerais, Brazil.

\section{How to cite this article:}

Mendonça FTNF, Santos AS, Buso ALZ, Malaquias BSS. Health education with older adults: action research with primary care professionals. Rev Bras Enferm [Internet]. 2017;70(4):792-9. [Thematic Edition “Good Practices: Fundamentals of care in Gerontological Nursing"] DOI: http://dx.doi.org/10.1590/0034-7167-2016-0349

Submission: 06-24-2016 Approval: 04-05-2017

\begin{abstract}
Objective: To assess the development and implementation of permanent education action. Method: Quantitative-qualitative research based on action research in three phases (diagnosis of reality, implementation of activity and evaluation), performed with health professionals and managers of basic health units. The evaluation was on the perception of changes immediately following the activity and after 120 days. Results: In the first phase, 110 professionals took part, 36.4\% of whom indicated the existence of groups for older adults at work. In the second phase, 98 professionals participated, pointing out interferences of the group in the life of older adults, items of importance and facilitation in forming groups and developing reality-based activities. The third phase showed, in the quantitative analysis, positive impact of the training, and in the qualitative analysis, reassessment of groups, greater knowledge and confidence in managing groups and increased respect for older adults. Final considerations: Permanent education opens pathways for the construction of differentiated care for older adults based on respect and health promotion.
\end{abstract}

Descriptors: Health Education; Older Adult; Professional Training; Continuing Education; Educational Assessment.

\section{RESUMO}

Objetivo: Avaliar o desenvolvimento e implementação de uma ação de educação permanente. Método: Pesquisa quantitativoqualitativa baseada na pesquisa-ação em 3 fases (diagnóstico da realidade, implementação de atividade e avaliação), realizada com profissionais de saúde e gerentes de unidades básicas. A avaliação se deu pela percepção de mudanças imediatamente à atividade e após 120 dias. Resultados: Na $1^{\text {a }}$ fase, participaram 110 profissionais, dos quais 36,4\% apontaram a existência de grupos para idosos no trabalho. $\mathrm{Na} 2^{\mathrm{a}}$ fase, participaram 98 profissionais, que apontaram interferências do grupo na vida do idoso, itens de importância e facilitação para construção de grupos e atividade baseada na realidade. A $3^{a}$ fase mostrou, na análise quantitativa, impacto positivo do treinamento; e, na qualitativa, releitura dos grupos e manejo com mais conhecimento, segurança e respeito ao idoso. Considerações finais: A educação permanente abre caminhos para a construção da atenção diferenciada aos idosos pautada no respeito e na promoção da saúde.

Descritores: Educação em Saúde; Idoso; Capacitação Profissional; Educação Continuada; Avaliação Educacional.

\section{RESUMEN}

Objetivo: Evaluar el desarrollo e implementación de un recurso de educación continua. Método: Investigación cuantitativa y cualitativa basada en la investigación-acción en tres etapas (diagnóstico de la realidad, implementación de la actividad, y evaluación) realizada con los profesionales sanitarios y los gestores de las unidades básicas. La evaluación se realizó por los cambios en la percepción de inmediato a la actividad, y después de 120 días. Resultados: En la primera etapa, 110 profesionales participaron, de los cuales 36,4\% apuntaron la existencia de grupos para los ancianos en el trabajo. En la segunda etapa participaron 98 profesionales, que apuntaron interferencia del grupo en la vida de los ancianos, artículos importantes y facilitación para construir grupos y actividades basadas en la realidad. En el análisis cuantitativo en la tercera etapa, se observó el impacto positivo de la formación; y en el análisis cualitativo, se observó la relectura de los grupos y la gestión con más 
conocimiento, seguridad y respeto a los ancianos. Consideraciones finales: La educación continua abre el camino para la construcción de una atención especial a los ancianos basada en el respeto y la promoción de la salud.

Descriptores: Educación para la Salud; Anciano; Desarrollo Profesional; Educación Continua; Evaluación Educacional.

\section{CORRESPNDING AUTHOR Francielle Toniolo Nicodemos Furtado de Mendonça Email: francielletoniolo.enf@gmail.com}

\section{INTRODUCTION}

Health education is a prominent aspect of the duties of primary health care (PHC) professionals, since an inherent feature in their work process is the development of educational action that may interfere in the health-disease process of the population, in the development of individual and collective autonomy and in the search for quality of life by users ${ }^{(1)}$.

The most recent literature on the subject basically includes two categories of health education action: traditional and dialogical. Traditional health education, also called preventive, is historically hegemonic, focusing on disease and healing intervention, and based on a biological theoretical and practical framework. It mainly involves learning about diseases, how to avoid them, their effects on health and how to restore $i^{(2)}$.

The dialogical health education model, which emerged with the consolidation of the Health Reform in the late 1980s, considers the roots of problems and has health promotion as its main objective. To reach this goal, it makes use of reflection and critical analysis on aspects of personal and collective reality, aiming to develop plans to transform reality. It is characterized by two-way dialogue between the parties involved in the process, breaking with the traditional model. In addition, it coincides with the guidelines of the current health system, such as autonomy and social control ${ }^{(2-4)}$.

It is known that the population is currently aging and that one of the ways to promote higher quality of life in aging is through health education action, especially when carried out in groups $^{(5-6)}$.

It is recommended that work with health education groups in basic health units be carried out by a multiprofessional team; however, it is observed that professionals are not always prepared for the development of such activities ${ }^{(1,7)}$. Therefore, studies point to the need for professional training to improve the performance of health education groups using a participatory and dialogic approach ${ }^{(4,8)}$.

Hence the importance of implementing Permanent Health Education (PHE) as a national policy for the training and development of health workers. PHE is described as an educational activity of a continuous character, whose guiding principle is the transformation of the work process. It is a practice focused on educational action based on daily services, starting out from a critical reflection on problems to ensure collective and interdisciplinary participation. This enables the construction of new knowledge and exchange of experiences, in an effort to transform health practices ${ }^{(9)}$.

Considering, on the one hand, the benefits afforded by health education groups for older adults, and, on the other, the deficiencies pointed out in the literature regarding the execution of such practices, it is observed that debates with the professionals that coordinate such groups are essential for their promotion.

Therefore, this study is justified for promoting action with health professionals with the ultimate goal of transforming practices related to health education groups with older adults, as well as providing a space for discussion that can contribute to the consolidation of the care model based on an expanded concept of health. Thus, the objective of this research was to evaluate the development and implementation of permanent education action geared towards primary care professionals, addressing the theme of "health education groups with older adults."

\section{METHOD}

\section{Ethical aspects}

The project was approved by the Research Ethics Committee of the Federal University of Triangulo Mineiro (opinion 1658/10) and the Municipal Health Department of Uberaba. All participants received explanations regarding the research and signed the Informed Consent Term (TCLE).

\section{Type of study}

This is a qualitative-quantitative approach that uses an action research methodology - a type of research that intends to make participants aware of reality, identify difficulties and solve problems through action, besides producing knowledge ${ }^{(10)}$.

\section{Methodological procedures}

\section{Study location}

The study was developed in the city of Uberaba, in the state of Minas Gerais. During the study period, the city had 35 Basic Health Units (BHU) and 51 Family Health Teams, 48 of which were associated with the oral health team. The Family Health Support Centers (FHSC) were composed of physicians (24), psychologists (10), physical therapists (06) and social workers (06). The coordination of the BHUs was under the responsibility of 25 managers.

\section{Population: inclusion and exclusion criteria}

The initial exploratory phase of the research included higher education health professionals who worked in the FHT/ FHSC and the BHU managers, excluding professionals who were relieved of their duties for any reason during the period of data collection.

The phases related to permanent education action and subsequent evaluation of the activity included professionals who participated in the activity, composed of UBS managers and 
middle-, technical- and higher-level professionals working in the FHT/FHSC, excluding those who were relieved of their duties for any reason during the period of data collection.

\section{Data collection and organization}

The first stage sought to identify the situation experienced by FHT/FHSC health professionals in the city of Uberaba MG regarding health education groups with older adults, as well as to raise themes for a possible educational activity on the subject. This was also the moment to inform the professionals about the project.

For this survey, a semi-structured, self-administered questionnaire was developed by the researchers. The instrument covered questions about sociodemographic data, health education groups in the basic health units and aspects related to professional training regarding the topic of health education with older adults. Data were collected between August and December 2013. The questionnaire was answered by 110 professionals, 89 of whom were health professionals and 21 of whom were managers.

The diagnosis of the situation concerning health education groups with older adults identified in the first stage was followed by the planning and implementation of the educational action, which was widely discussed among researchers and representatives of the Municipal Health Department (MHD) of Uberaba-MG.

A total of 98 professionals took part in the educational action, divided into three groups. The participants were defined in common agreement considering their own interests and those of the managers of the basic health units and of the municipal health department. The meetings were held weekly between May and August 2014, the first group in May, the second in July and the last in August, in the premises of the Federal University of Triângulo Mineiro (UFTM). Each group took part in four 16-hour face-to-face meetings. It is important to note that the activity was carried out within the working hours of the professionals.

The permanent education activity was developed based on a participatory and dialogic methodology, allowing exchange of experiences and discussion of the possibilities of implementing action ${ }^{(11)}$.

The last stage of the research, evaluation of educational action (developed in two steps), was carried out using a questionnaire about the professionals' perception on the last day of the course (of each class) and a questionnaire about the application of knowledge at work after 120 days of permanent education.

For the first step of evaluation, a semi-structured, self-administered questionnaire was developed by the researchers. The instrument contained questions on the sociodemographic and professional profile of the participants and open questions about their perception regarding the creation and management of health education groups with older adults and the applicability of the educational action in which they took part. The instrument was administered on the last day of activity of each group and answered by 66 participants who attended the meeting and accepted to participate in the evaluation.
Subsequently, between 120 and 150 days after the end of each educational activity group ( $2^{\text {nd }}$ step), that is, between October 2014 and January 2015, the professionals were contacted for the administration of a questionnaire to identify the effects of the permanent education activity on their behavior, as well as the support received by the professionals to apply in the workplace the practices resulting from the discussions in the permanent education action of which they took part.

The evaluation in this second step was answered by 86 participants. Losses were due to refusals (9), withdrawals (2) and retirement (1). Data collection was based on training impact and transfer support scales ${ }^{(12-13)}$, as well as two open questions, giving participants the opportunity to express freely whether there was any change in their practice after the educational activity and how it occurred.

\section{Data analysis}

Quantitative data were input in a Microsoft Excel spreadsheet and the databases were exported to the software Statistical Package for Social Sciences (SPSS) version 20.0, for analysis. The scales used presented satisfactory internal consistency, with Cronbach's alpha coefficients of 0.876 and 0.864 , showing that the original structure of the instrument was maintained in the study population. Correlation analysis was performed between the scales using Spearman's coefficient, classified according to Bussab and Morettin ${ }^{(14)}$.

For the qualitative analysis the material resulting from the answers to the open questions was transcribed in full and submitted to the Collective Subject Discourse (CSD) methodology, a strategy that presents the thoughts of a collectivity through a synthesized speech written in first person singular. According to the CSD, discourses are composed of key expressions $(\mathrm{KE})$, which are the most significant parts of each statement, containing the same main idea (MI) and/or anchor ${ }^{(15)}$. To support the processing of the statements and the construction of the CSDs, the software Qualiquantisoft version 1.3c was used.

Regarding the assessment of the applicability of educational action, the discourses recognized that health education groups can interfere in the life of older adults, considered important aspects in the management of these groups and pointed to training as a facilitator in creating groups and promoting reflection on practice, with possibilities of applying knowledge. After 120 days of action, the discourses revealed a reassessment of groups and diversification of resources used, greater knowledge and security in conducting groups and increased respect towards older adults.

\section{RESULTS}

In the first stage of the research, the diagnosis of health education groups with older adults, of the 221 PHC professionals invited to participate, 110 answered the questionnaire. Among them, $80.9 \%$ were health care professionals and $19.1 \%$ had managerial positions in basic health units. The majority of professionals were female $(81.8 \%)$ and the predominant age group was 41 to 50 years old (29.2\%). "It is emphasized that in the city, basic health unit managers are 
appointed by the head of the municipal health department, and are not necessarily professionals with a background in health."

Regarding the training of professionals, the majority were nurses $(45 \%)$, followed by dentists $(19.8 \%)$. Professionals with 10 to 20 years of experience $(27.2 \%)$ and more than 5 years working at the PHC (56.8\%) were predominant.

Regarding health education groups, $97.3 \%$ of professionals reported the development of some type of group in their unit. The majority considered important the participation of older adults in groups (96.4\%); however, only $36.4 \%$ reported the existence of specific groups for older adults in their units. Concerning the frequency of meetings, they were usually weekly $(42.1 \%)$ or monthly $(25.9 \%)$. Regarding group coordination, $42.1 \%$ reported the groups were coordinated by nurses, $42.1 \%$ by multiprofessional teams, $7.9 \%$ by physical therapists and $7.9 \%$ by technicians and other professionals.

The theme of the group was mainly defined from the needs observed by the professional $(46.1 \%)$, and the most discussed topics were physical activity $(90 \%)$, eating habits $(85 \%)$ and lifestyle (75\%).

Regarding the professionals' knowledge about health education, $55.1 \%$ stated that their educational background did not offer enough training for this practice, and $64 \%$ reported that this subject is not discussed in permanent education activities.

According to the participants, in order to conduct health education groups with older adults, professionals need knowledge about dynamics (82.7\%), diseases and injuries (77.3\%), group planning $(74.5 \%)$, teaching methods $(68.2 \%)$ and publicizing activities (54.5\%).

Following the analysis of data from the first stage and discussion meetings with representatives of the MHD, as well as health unit managers, the themes and plan for the permanent education activity were defined and the professionals were invited to participate.

Participants of the PHE activities included health professionals and PHC managers of three health districts of the city of Uberaba-MG, totaling 98 professionals. Of those, 86 participants responded the questionnaire. There was a predominance of female participants $(89.5 \%)$ and those in the age group of $31-50$ years $(54.6 \%)$. Most of them were nurses $(29.1 \%)$, followed by community health agents $(24.4 \%)$ and dentists $(16.3 \%)$, with 5 to 10 years of training $(30.9 \%)$. Most of the participants $(95.3 \%)$ reported being involved in some health education group, $45.1 \%$ as leaders/ coordinators.

In order to achieve PHE objectives, group dynamics and life experiences were used, usually with problematization based on prior knowledge about health education and the participants' practical reality.
There was the additional support of professionals in the areas of nutrition, nursing, occupational therapy, physical education, physical therapy, medicine and homeopathy (invited by UFTM or not linked to the university and professionals other than the ones being trained), who provided technical frameworks on the issues discussed. Despite the presence of invited professionals, the participants themselves were responsible for researching the themes and presenting them for discussion, and only then would the guests intervene.

The themes included organizational aspects of health education action, teaching techniques to implement activities, topics of interest of older adults and the major health problems in old age. At the last meeting of each group, there was a closing event and evaluation of the activity.

The evaluation carried out on the last day of the course sought to identify the professionals' perception regarding the applicability of PHE action. Based on the analysis of the responses according to the CSD methodology, nine Main Ideas were identified, which are the syntheses of the content manifested in the selected KEs, presented in Figure 1.

To complement the evaluation of the PHE action and identify the influence of the activity on the professionals' work, a new evaluation was performed 120 days after the end of the permanent education activity ( $2^{\text {nd }}$ evaluation step).

Regarding the evaluation using the scale of impact of training on work, a positive impact of training was observed: on a scale of 1 to 5 , the mean impact was $3.83(\mathrm{SD}=0.51$ ). Concerning support to training transfer, the results were also positive, however with means between 2.45 and 3.05, lower than impact of training on work. The lowest result was related to material support, with a mean of $2.45(\mathrm{SD}=0.76)$. The data are presented in Table 1.

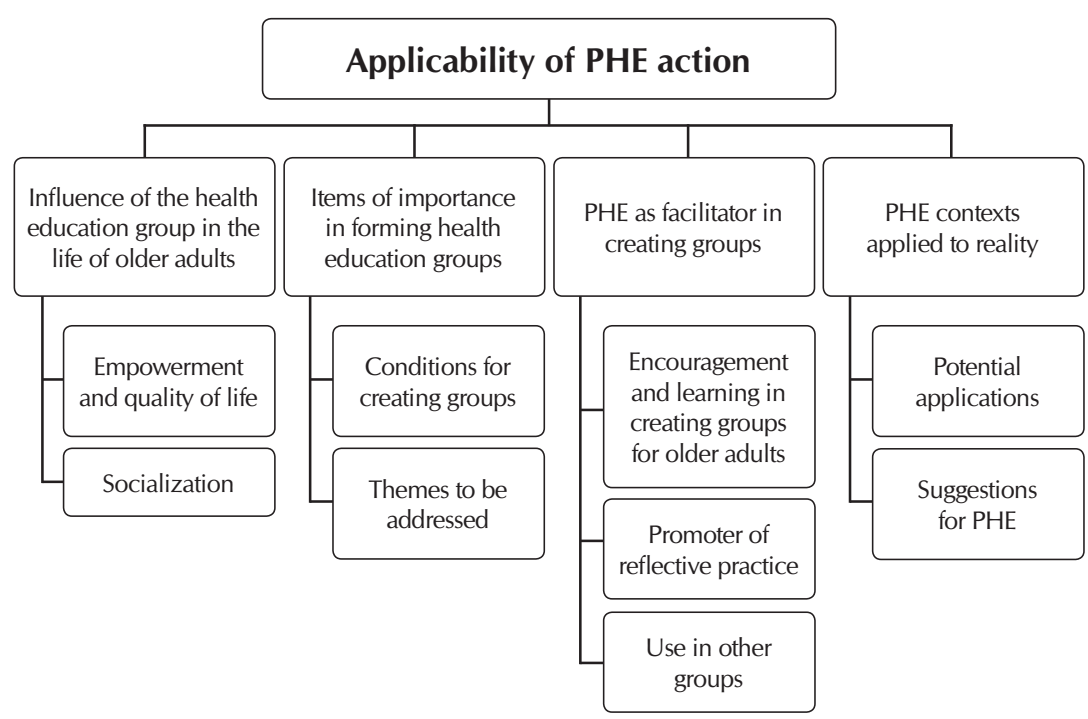

Note: PHE - Permanent Health Education.

Figure 1 - Synthesis of the Main Ideas identified in the discourses of participants regarding their perception of the applicability of action immediately following the activity, Uberaba, Minas Gerais, Brazil, 2104 
Table 1 - Assessment of impact and support of Permanent Health Education action 120 days after the educational activity, Uberaba, Minas Gerais, Brazil, 2014

\begin{tabular}{lccccc}
\hline \multicolumn{1}{c}{ Impact/Support } & Mean & Standard Deviation & Minimum & Median & Maximum \\
\hline Impact of training on work & 3.83 & 0.51 & 2.25 & 3.75 & 5.00 \\
Situational support factors & 2.87 & 0.57 & 1.56 & 2.78 \\
Consequences associated with the use of new skills & 3.05 & 0.55 & 1.57 & 3.00 & 4.22 \\
Material Support & 2.45 & 0.76 & 1.00 & 2.33 \\
\hline
\end{tabular}

Table 2 - Correlation between impact of training on work and transfer support scales, Uberaba, Minas Gerais, Brazil, 2014

\begin{tabular}{|c|c|c|c|c|c|}
\hline & \multirow[b]{2}{*}{ Impact } & \multicolumn{2}{|c|}{ Psychosocial Support } & \multirow[b]{2}{*}{$\begin{array}{l}\text { Material } \\
\text { Support }\end{array}$} & \multirow[b]{2}{*}{$\begin{array}{l}\text { Support to training } \\
\text { transfer }\end{array}$} \\
\hline & & $\begin{array}{l}\text { Situational } \\
\text { factors }\end{array}$ & $\begin{array}{l}\text { Consequences associated } \\
\text { with the use of new skills }\end{array}$ & & \\
\hline \multirow{2}{*}{$\begin{array}{l}\text { Impact of } \\
\text { Training on Work }\end{array}$} & Correlation coefficient & 0.203 & 0.143 & $0.426^{*}$ & $0.321^{*}$ \\
\hline & $p$ value & 0.060 & 0.188 & 0.000 & 0.003 \\
\hline
\end{tabular}

Note: ${ }^{*} p<0.01$

The analysis of the relationship between impact of training on work and support to training transfer showed that there was a significant but weak positive correlation between them $(r=$ 0.321). It is observed that when the factors of the transfer support scale were separated, material support showed the highest correlation with impact. The data are shown in Table 2.

In addition to the impact on work and support to training transfer scales, the following questions were also posed to the professionals: "Do you believe this training has in any way modified your action regarding health education with older adults? If so, how?" and "Is there anything you learned in the training that you have used in your work up to now?" Due to the similarity, all responses were analyzed together, giving rise to five Main Ideas. Figure 2 features the synthesis of the MIs.

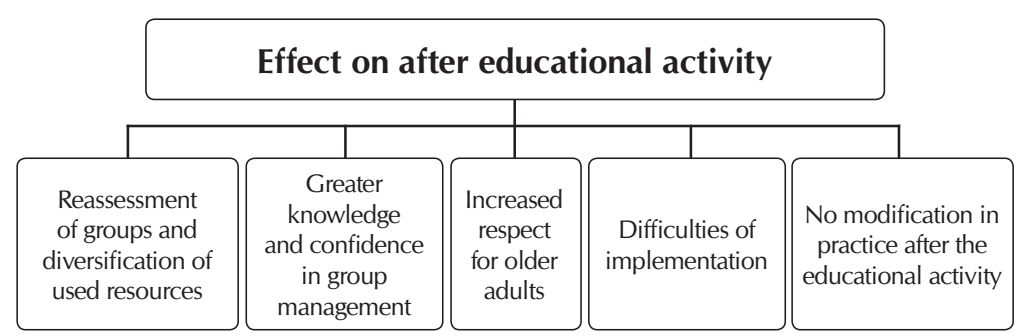

Figure 2 - Synthesis of the Main Ideas identified in participants' discourses regarding the effects of Permanent Health Education action on work, 120 days after of the educational activity, Uberaba, Minas Gerais, Brazil, 2014

\section{DISCUSSION}

The study of characteristics in the health sector, especially in $\mathrm{PHC}$, can contribute to define priorities, as well as emphasize the needs of educational action in service to meet the demands of the population.
In this study, $36.4 \%$ of professionals reported conducting health education groups with older adults, a result superior to that found in the literature ${ }^{(16-17)}$. However, most health education groups lack regularity and are highly dependent on microenvironments. The organization of such groups is directly related to the profile of professionals, their work objectives and commitment to FHT principles ${ }^{(18)}$.

The themes addressed in the group should be suggested a priori by users and related to health promotion and disease prevention. Figueiredo, Rodrigues-Neto and Leite ${ }^{(19)}$ evidenced the non-participation of users in the choice of themes to be addressed, besides the lack of development of action elaborated according to epidemiological profile.

The literature often reports that the development of these groups still occurs according to the traditional model, focused on the disease and healing proposal, demonstrating the weaknesses in the implementation of health education action and the challenges in consolidating health-promoting practice $\mathrm{p}^{(17,19-20)}$.

Corroborating other research, in this study $64 \%$ of participants reported that knowledge about health education groups is not an object of reflection in permanent education action, evidencing the need for discussion spaces that stimulate the exchange of experiences and transformation of practice to meet the demands of the population ${ }^{(7-8,17,19)}$.

Regarding action assessment, according to the reports given immediately after the activity, it was observed that participants acknowledged that health education groups can interfere in the life of older adults, either as an instrument for empowerment and quality of life or as a space for socialization. They also described the training as a facilitator in creating groups for promoting encouragement and learning, enabling reflective practice and allowing the use of this knowledge in other groups.

Regarding participants' perception, studies show that the use of group health education activities can contribute to 
the appreciation of life, self-care, personal growth and active health promotion, favoring active aging with better quality of life for older adults ${ }^{(5-6)}$.

The professionals highlighted in the evaluation the main items of importance for the creation of health education groups, among them the concern to meet local demands, representing an advance in terms of horizontal and dialogic education, which seeks to meet the needs of those who take part in the action and not of the professionals ${ }^{(3)}$.

It is also observed, according to the reports, that the activity was in accordance with PHE principles, which are based on meaningful learning and encourage reflection on the different realities in which professionals are inserted in order to identify problem situations, contributing to professional development and enabling changes in professional practice ${ }^{(9)}$.

Regarding the impact of the educational activity on work, the results of the quantitative evaluation carried out 120 days after the implemented action indicated positive self-assessment, with a mean of 3.83 in the evaluation of impact of training on work, higher than that presented by Alavarce ${ }^{(21)}$ in a survey carried out with higher education primary and secondary care professionals in reference to an online course. On the other hand, two other studies, both with only one professional category each, presented higher means than those of this study ${ }^{(22-23)}$.

It should be emphasized that the fact that individuals are unable to apply what they learned in an educational action does not necessarily mean failure of action, since other contextual variables, such as support, may influence the transfer of training. The results found in this study pointed to the existence of a significant positive correlation between impact of training on work and transfer support, a correlation already indicated in other studies ${ }^{(24)}$.

The assessment of professionals regarding the material support needed to apply the content discussed in the PHE action was the one that showed the lowest figures, with a mean of 2.45 $(\mathrm{SD}=0.76)$ on a scale of 1 to 5 . This result corroborates the findings by Alavarce ${ }^{(21)}$ and differs from the study by Bastos ${ }^{(22)}$; however, it must be considered that the latter occurred in a hospital environment, a different context compared to primary care.

Dissatisfaction with the lack of material resources was also pointed out by professionals in the open questions as one of the difficulties for the implementation of health education groups, corroborating other studies ${ }^{(25-26)}$.

It should be emphasized that although material resources are necessary, their mere shortage should not be a justification for not implementing health education groups. However, it is acknowledged that the scarcity of material resources, together with other difficulties encountered by professionals such as lack of managerial support, high demand for healing and individual action and depreciation of educational action, can be demotivating with regards to organizing groups.

In the qualitative evaluation, the professionals' discourses indicated reassessment of groups and diversification of used resources, greater knowledge and confidence in organizing groups and increased respect for older adults. Difficulties were also cited regarding the implementation of activities.

Work conducted with openness to change and the use of varied resources facilitates dialogue and proximity among group members, besides making the activity more enjoyable and increasing the development of participants' knowledge $\mathrm{e}^{(27)}$.

It is extremely important to conduct the health education group according to the characteristics of the population in question. It is known that the aging process includes multiple particularities and is not a homogenous process for everyone. In this sense, recognizing and accepting the group's profile contributes input to the planning, emphasizing the expectations and needs to be addressed, using appropriate measures for an effective approach to the group ${ }^{(4,28)}$.

In addition, it is expected that increased respect for older adults and the acknowledgment of their autonomy will strengthen the relationship between professionals and older adults. The establishment of this relationship is essential to achieve the objectives proposed by the group, since adherence and self-care practice are closely linked to care based on trust, bonding and respect for users' wishes, enabling the development of favorable health-promoting therapeutic proposals ${ }^{(29)}$.

In assessing the difficulties in implementing groups, participants pointed to the persisting unwillingness and lack of cooperation of some professionals, including health unit managers. This difficulty was also cited by other researchers ${ }^{(25)}$.

Many health managers, supervisors and professionals today do not view educational intervention as health care and show no interest in "wasting time" with this type of activity, preferring the traditional method of consultation and prescription drugs, preventing changes in the current care model ${ }^{(29)}$.

The MI with fewer key expressions in the evaluation relates to the training as a confirmation of activities already adopted by some professionals. The CSD was elaborated from six reports, a lower proportion compared to a study by Mourão, Abbad and Zerbini ${ }^{(30)}$ with 742 participants, in which $48 \%$ reported already possessing the necessary knowledge and skills to express the abilities taught in the evaluated course.

However, the fact that these professionals previously carried out the activities discussed in the PHE should not exclude them from participating of those activities, since such occasions promote the exchange of experience and improvement of knowledge, enabling such professionals to both remedy possible shortcomings and share their experiences with the other participants.

Contributions to the area of nursing, health or public policy

The research contributed to nursing and to the possibility of improving care for older adults as public policy, inasmuch as it raised needs, developed permanent education action and accompanied the creation of educational groups. Moreover, in all of those phases the study assessed the impact of this practice with older adults. This was helped by the use of active methodologies throughout the process.

\section{Limitations of the study}

The limitations of the study relate to those inherent to the action research process. The objective of the work was situational and specific, according to local reality and possibilities. In addition, the researcher had no control over all variables, 
as they occurred in a real context, with social actors endowed with autonomy and playing an active role.

\section{FINAL CONSIDERATIONS}

Health education groups are tools capable of promoting the exchange of experience and fostering self-care and autonomy among older adults. However, several difficulties persist for these groups to achieve a preferential and permanent space in primary care.

Change is needed in the traditional way of carrying out permanent action with health professionals, and also in the traditional way of conducting health education groups. It is necessary to go beyond recurrent biomedical themes such as illness, medication, complications and treatment to include other themes such as leisure, exchange of popular experiences and healthy community cooking, among so many other possibilities to be addressed in health education groups with older adults.
It should be emphasized that greater support from managers in this process is essential. The transformation of practices to assume a broader view of health brings benefits for all involved. However, favoring group educational activities over healing action implies a paradigm shift that must be supported by the main coordination bodies, which have the power to encourage or discourage certain practices.

It is hoped that the study has contributed to the production of knowledge on educational action with health professionals according to the principles of PHE, demonstrating that permanent education opens pathways for the development of differentiated care for older adults, based on respect and confidence in the feasibility of carrying out educational work focused on health promotion.

\section{FUNDING}

We thank the support of Fundação de Amparo à Pesquisa do Estado de Minas Gerais (FAPEMIG).

\section{REFERENCES}

1. Brasil. Ministério da Saúde. Política nacional de atenção básica [Internet]. Brasília: Ministério da Saúde. 2012[cited 2016 Apr 05]. Available from: http://189.28.128.100/dab/docs/publicacoes/geral/pnab.pdf

2. Mascarenhas NB, Melo CMM, Fagundes NC. [Production of knowledge on health promotion and nurse's practice in Primary Health Care]. Rev Bras Enferm [Internet]. 2012 [cited 2016 Apr 05];65(6):991-9. Available from: http://www.scielo.br/pdf/reben/ v65n6/a16v65n6.pdf Portuguese.

3. Maciel MED. Education in health: concepts and intentions. Cogitare Enferm [Internet]. 2009 [cited 2016 Apr 05];14(4):773-6. Available from: http://www2.fct.unesp.br/docentes/geo/raul/geografia da saude-2014/leitura $\% 202 /$ educa $\%$ E7 $\%$ E3o $\% 20$ em $\% 20$ sa \%FAde\%202.pdf

4. Alvez GG, Aerts D. Health education practices and Family Health Strategy. Ciênc Saúde Colet [Internet]. 2011 [cited 2016 Apr 05];16(1):319-24. Available from: http://www.scielo.br/pdf/csc/v16n1/v16n1a34.pdf

5. Serbim AK, Gerlack LF, Marchi DSM, Gaviolli C, Cecconello M, Moreira LB, et al. Multiprofessionals workshops: health education for elderly's community. Rev Eletrônica Gest Saúde [Internet]. 2013 [cited 2016 Apr 05];4(1):1780-90. Available from: http:// gestaoesaude.unb.br/index.php/gestaoesaude/article/view/242

6. Campos CNA, Santos LC, Moura MR, Aquino JM, Monteiro EMLM. [Reinventing nursing practice in health education: theater with elderly]. Esc Anna Nery [Internet]. 2012 [cited 2016 Apr 06];16(3):588-96. Available from: http://www.scielo.br/pdf/ean/v16n3/23.pdf Portuguese.

7. Oliveira SRG, Wendhausen ALP. [Resignifying education in health: difficulties and possibilities of the family health strategy]. Trab Educ Saúde [Internet]. 2014 [cited 2016 Apr 07];12(1):129-47. Available from: http://www.scielo.br/pdf/tes/v12n1/08.pdf Portuguese.

8. Falkenberg MB, Mendes TPL, Moraes EP, Souza EM. [Health education and education in the health system: concepts and implications for public health]. Ciênc Saúde Colet [cited 2016 Apr 07]. 19(3)847-52. Available from: http://www.scielo.br/pdf/ csc/v19n3/1413-8123-csc-19-03-00847.pdf Portuguese.

9. Brasil. Ministério da Saúde. Política nacional de educação permanente em saúde[Internet]. Brasília: Ministério da Saúde, 2009 [cited 2016 Apr 07]. Available from: http://bvsms.saude.gov.br/bvs/publicacoes/politica_nacional_educacao_permanente_saude.pdf

10. Thiollent M. Metodologia da pesquisa-ação. 18a ed. São Paulo: Cortez; 2011. p. 135.

11. Freire P. Pedagogia do oprimido. $42^{\mathrm{a}}$ ed. Rio de Janeiro: Paz e Terra; 2005.

12. Abbad G. Um modelo integrado de avaliação do impacto do treinamento no trabalho. IMPACT. [Tese]. Brasília: Universidade de Brasília, Instituto de Psicologia; 1999.

13. Abbad G, Sallorenzo LH. Desenvolvimento e validação de escalas de suporte à transferência de treinamento. Rev Adm [Internet]. 2001 [cited 2016 Apr 10];36(2):33-45. Available from: http://rausp.usp.br/wp-content/uploads/files/v36n2p33a45.pdf

14. Bussab WO, Morettin PA. Estatística Básica. 6a ed. São Paulo: Saraiva; 2010.

15. Lefevre F, Levefre AM. Pesquisa de representação social: um enfoque qualiquantitativo. 2a ed. Brasília: Liber Livro; p. $2012-224$.

16. Assunção APF, Barbosa CR, Teixeira E, Medeiros HP, Tavares IC, Sabóia VM. Health educational praxis of the male nurses of the 
Family Health Strategy. Rev Enferm UFPE [Internet]. 2013 [cited 2016 Apr 13];7(11):6329-35. Available from: http://www.revista. ufpe.br/revistaenfermagem/index.php/revista/article/4185/7671

17. Roecker S, Marcon SS. [Health education in the family health strategy program: the meaning and praxis of nurse]. Esc Anna Nery Rev Enferm [Internet]. 2011 [cited 2015 Apr 13];15(4):701-9. Available from: http://www.scielo.br/pdf/ean/v15n4/a07v15n4.pdf Portuguese.

18. Maffacciolli R, Lopes MJM. Groups in basic health attention in Porto Alegre: uses and forms of therapeutic intervention. Ciênc Saude Colet [Internet]. 2011 [cited 2016 Apr 16];16(1):973-82. Available from: http://www.redalyc.org/pdf/630/63018473029.pdf

19. Figueiredo MFS, Rodrigues-Neto JF, Leite MTS. [Health education in the context of Family Health from the user's perspective]. Interface Comun Saúde Educ [Internet]. 2012 [cited 2016 Apr 16];16(41):315-29. Available from: http://www.scielo.br/pdf/icse/ v16n41/a03v16n41.pdf Portuguese.

20. Mendonça FF, Nunes EFPA. Participatory activities in health education groups for chronic sick. Cad Saude Colet [Internet]. 2014 [cited 2016 Apr 17];22(2):200-4. Available from: http://www.scielo.br/pdf/cadsc/v22n2/1414-462X-cadsc-22-02-00200.pdf

21. Alavarce DC. Development and evaluation of reaction, learning and impact of e-learning on health professionals [Tese]. São Paulo: Escola de Enfermagem da Universidade de São Paulo, Curso de Enfermagem; 2014 [cited 2016 Apr 16]. Available from: http://www.teses.usp.br/teses/disponiveis/7/7140/tde-17122014-111420/pt-br.php

22. BASTOS LFL. Assessment of reaction, learning and impact of training in a hospital of the city of São Paulo [Dissertação]. São Paulo: Escola de Enfermagem da Universidade de São Paulo, 2012 [cited 2016 Apr 16]. Available from: http://www.teses.usp.br/teses/ disponiveis/7/7140/tde-03012013-175327/pt-br.php

23. Freitas CPP, Habigzang LF, Koller SH. [Evaluation of a Training for Psychologists Working with Victims of Sexual Abuse]. Psico [Internet]. 2015 [cited 2016 Apr 20];46(1):38-45. Available from: http://revistaseletronicas.pucrs.br/ojs/index.php/revistapsico/ article/viewFile/16718/12945 Portuguese.

24. Zerbini T, Abbad G. Training transfer and work training impact: critical literature analysis [Internet]. 2010 [cited 2016 Apr 25];10(2):97-111. Available from: https://periodicos.ufsc.br/index.php/rpot/article/view/22212/20149

25. Roecker S, Budo MLD, MARCON SS. The educational work of nurses in the Family Health Strategy: difficulties and perspectives on change. Rev Esc Enferm USP [Internet]. 2012 [cited 2016 May 03];46(3):641-49. Available from: http://www.scielo.br/pdf/ reeusp/v46n3/16.pdf

26. Moutinho CB, Almeida ERA, Leite MTS, Vieira MA. [Difficulties, challenges, and overcoming in health education in the view of family health nurses]. Trab Educ Saúde [Internet]. 2014 [cited 2016 May 05];12(2):253-72. Available from: http://www.scielo.br/ $\mathrm{pdf} / \mathrm{tes} / \mathrm{v} 12 \mathrm{n} 2 / \mathrm{a} 03 v 12 \mathrm{n} 2 . \mathrm{pdf}$ Portuguese.

27. Mallamann DG, Galindo Neto NM, Sousa JC, Vasconcelos EMR. Health education as the main alternative to promote the health of the elderly. Ciênc Saude Colet [Internet]. 2015 [cited 2016 May 06];20(6):1763-72. Available from: http://www.scielo.br/pdf/ csc/v20n6/1413-8123-csc-20-06-1763.pdf

28. Motta LB, Aguiar AC, Caldas CP. [The Family Health Strategy and healthcare for the elderly: experiences in three Brazilian cities]. Cad Saúde Pública [Internet]. 2011 [cited 2016 May 13];27(4):779-86. Available from: http://www.scielo.br/pdf/csp/v27n4/17. pdf Portuguese.

29. Taddeo OS, Gomes KWL, Caprara A, Gomes AMA, Oliveira GC, Moreira TMM. [Access, educational practice and empowerment of patients with chronic diseases]. Ciênc Saude Colet [Internet]. 2012 [cited 2016 May 12];17(11):2923-30. Available from: http:// www.scielo.br/pdf/csc/v17n11/v17n11a08.pdf Portuguese.

30. Mourão L, Abbad GS, Zerbini T. [Evaluation of the effectiveness and predictors of a distant training in a large bank]. Rev Adm [Internet]. 2014 [cited 2016 May 13];49(3):534-48. Available from: http://www.scielo.br/pdf/rausp/v49n3/a08v49n3.pdf Portuguese. 